\title{
An Interview with Jeremy Munday
}

ADITYA KUMAR PANDA

Jeremy Munday (hereafter $\mathbf{J M}$ ) is a professor at the Centre for Translation Studies, University of Leeds, UK. He is the author of Introducing Translation Studies (2001 \& 2016), Style and Ideology in Translation (2008), Evaluation in Translation (2012), and co-author, with Basil Hatim, Of Translation: An Advanced Resource Book (2004). Munday has also edited many noteworthy books on Translation Studies. He has been focusing on the approaches of Discourse Analysis, Stylistics, and appraisal theory to translation in the contexts of Spain and Latin America. Aditya Kumar Panda (hereafter AKP) is an assistant editor of the Translation Today who interviews Jeremy Munday.

AKP: Translation Studies is a well-established discipline now. Does it have anything specific that makes it distinct from other disciplines like Linguistics, Cultural Studies or Comparative Literature? I wonder what would be the disciplinary boundary of Translation Studies or should one, at all, think about such a boundary?

JM: I think Translation Studies is distinctive on a basic level by its focus on translation. I know this sounds obvious, but we must always remember that linguistics, cultural studies and comparative literature have a different focus, one that has applications for our subject but not one that is primarily placing translation at its centre. I think that Translation Studies looks at all facets of translation, whether from the perspective of discourse analysis, machine translation, localization, globalization, world literature or the workings of translation at different historical moments. So I see Translation Studies as being typically interdisciplinary and it is becoming more 
prominent these days and has a dynamic which attracts researchers from other disciplines.

AKP: India has a rich translation tradition. The Western and Indian notions of translation exhibit remarkable differences. You surveyed the translation theory before the twentieth century with no discussion of Indian and Chinese traditions of translation in the $1^{\text {st }}$ edition of Introducing Translation Studies, although the subsequent editions discussed it. How would you theorize the notions of translation relevant to the traditions prevalent in India \& China?

JM: The $1^{\text {st }}$ edition of Introducing Translation Studies was written in 1999-2000 and published in 2001. My initial idea was to bring together western theories that I had studied at $\mathrm{PhD}$ level. We must remember that at the time this material was very dispersed and some of the material was not widely available in English, which, rightly or wrongly, has become a lingua franca for much academic work, ironically even in Translation Studies. The focus was on western translation studies which I think reflects much of the thinking of the time in the contexts in which I was working. Subsequent editions have reflected other non-western traditions and have tried to show that concepts of translation are very different in different parts of the world. I have to admit I am no expert on the development of Indian and Chinese traditions (I have scarcely scratched the surface of India, with its multiplicity of languages), aside from noting the obvious features of different discourses and of an environment in which different key cultural and religious texts have been produced. Fortunately, I have learnt from other scholars' writing about these rich traditions.

AKP: The evaluation of a translation is a subjective phenomenon. Therefore, evaluation may vary from individual 
to individual and from text to text. How far a translator intervenes in the evaluation? Why should we consider the interpersonal function of a translation above the textual and the ideational functions?

JM: My interest in evaluation and of the interpersonal function was that it might capture some of the subtleties of positioning of the translator/interpreter as a third communicator in the translation event. So, writer/speaker to reader/listener in the source language becomes much more complicated when a translator or interpreter enters the scene. That is not to say that the interpersonal function is more important than the textual and the ideational functions. Clearly, a distortion or shift in the ideational level and denotational meaning can be far more crucial than the interpersonal function. However, that kind of ideational shift is either brought about by severe intervention or lack of performance by the translator, whereas the changes in the interpersonal function are always there, simply because of the addition of the third element and that is what interests me.

AKP: How does a style determine the translators' decision making process?

JM: If we speak about style we need a definition. My interest in Style and Ideology is how far a translator's idiosyncratic choices might be displayed in texts of very different types. I looked, amongst others, at Gregory Rabassa's translations of a whole range of Latin American authors from the 1960s onwards. Style also works the other way. For example, what happens when a particular style of an author is translated by various translators? There, it is a question of finding patterns of translation choices. I don't think that translation choices are totally determined by a translator's stylistic preferences of lexis or syntax, but they are subject to a conscious or 
subconscious selection from the linguistic repertoire of the translator and, as I saw in Style and Ideology, very often this is reflected by favourite phraseology, especially in the translation of dialogue.

AKP: Can there be a kind of theorization on translation that is applicable across the world languages? Do you think translation universals exist?

JM: It is very difficult to theorize on translation across all world languages. Even between cognate languages is relatively limited. My wish would be to understand all languages in the world but with 6000 or more this would be quite problematic, I fear. A question is how useful are the kind of universals that have been proposed so far, such as Toury's laws of growing standardization and interference. But these are important starting points for understanding how translation works and in framing questions such as the conditions under which such tendencies prevail.

AKP: Ideology is an indispensable element in all writings. And, translation, as a form of writing, is not an exception. How would you perceive the statement that all types of translations are ideologically driven?

JM: I've said, I think, in my writing that translation is ideologically driven if we understand ideology as bringing a translator's world view to bear on the task at hand. However hard a translator might try to be a dispassionate mediator, I think it is always the case that the translator brings his or her personality, education and preferences to a text. That doesn't mean to say that a translator would distort a text but that some of the linguistic choices may be bound to his/her upbringing and implicit realizations of background may lie below the surface. There is also the question of what happens when a translator is asked to translate a text which he/she profoundly 
disagrees. That is an ethical choice whether to accept the commission which affects every translator at some point in their career.

AKP: How would the availability of the tools of corpus linguistics help the translators attaining consistency in their translations?

JM: In our training at the University of Leeds we place a lot of emphasis on the use of computer-assisted translation tools which, as is well known, make use of a corpus of existing translations (a translation memory) in order to suggest or determine future translation equivalence. This has a positive effect on consistency but has negative consequences also. One is that many translation companies pay less for material that has already been translated even when that requires careful decision making and assessment from the translator as to the appropriateness of the designated chunk of material.

I also work with colleagues at Leeds who construct corpora in order to understand the workings of the language. This is an area which has huge potential not only for translators but for linguists in any language.

AKP: Discourse Analysis is important in training translators that is emphasized in your recently edited book Discourse Analysis in Translation Studies (2017). How far Discourse Analysis is successful in analysing a text that is to be translated into a language? Why has it not received the attention it deserves?

JM: With colleagues I have worked on Discourse Analysis and publications in that area over the recent years. We have a special issue of the journal Perspectives which is coming out in 2018 and a special panel at the IATIS conference in Hong Kong in July 2018. Discourse Analysis is an advance on text analysis in that it looks at how the text functions in its socio- 
cultural context and how language is used not just to communicate in one text but in order to construct identity and power relations across texts in a specific cultural context. I think great advances were made in the 1990s through the work of House, Hatim \& Mason and Baker, amongst others, and some of these findings were particularly relevant to translator training. In more recent years the move to cultural, sociological and historical perspectives of translation shouldn't obscure the fact that to do any critique of a text we need a firm model of text and discourse analysis. While it might have its origins in linguistics, it needs to be specially tailored for the translation context. I feel that our recent work and publications are very promising in moving attention back to discourse analysis, especially as it embraces multimodality and new genres of writing and communicating.

AKP: Translation Studies is becoming interdisciplinary and also trans-disciplinary. Theoretically, it is gaining new insights not only from Linguistics and Comparative Literature but also from Sociology, Anthropology, Psychology and Philosophy. Technologically, the field is broadening itself with many Machine tools and online resources. What are your views on such developments in Translation Studies?

JM: In general, I welcome the broadening of focus of Translation Studies and especially when it brings us into contact with academics and others working in other disciplines. My one concern is that this might lead to fragmentation or a dilution of the focus of the translation as external disciplines seeks to move in and take advantage of the popularity of translation. We shouldn't lose sight of the fact that the core element of translation remains the interlingual translation between two languages. However, the exciting point is the way in which translation is conceived may vary to 
encompass a whole range of different communicative situations.

AKP: What do you think about the future of Translation Studies as an academic discipline?

JM: I'm positive because I have seen how Translation Studies has developed over the last 25 years from something which was very marginal to something which is becoming increasingly central to work in the Arts and Humanities. I have seen how Translation Studies has grown over the world and how the number of conference, publications, colleagues has risen hugely. This has been a very exciting time to be involved in Translation Studies and I feel privileged to have lived through that and contributed a little bit to its popularity and advances. When I look around me and see the number of highly competent young colleagues involved in Translation Studies I feel very confident in its future. 